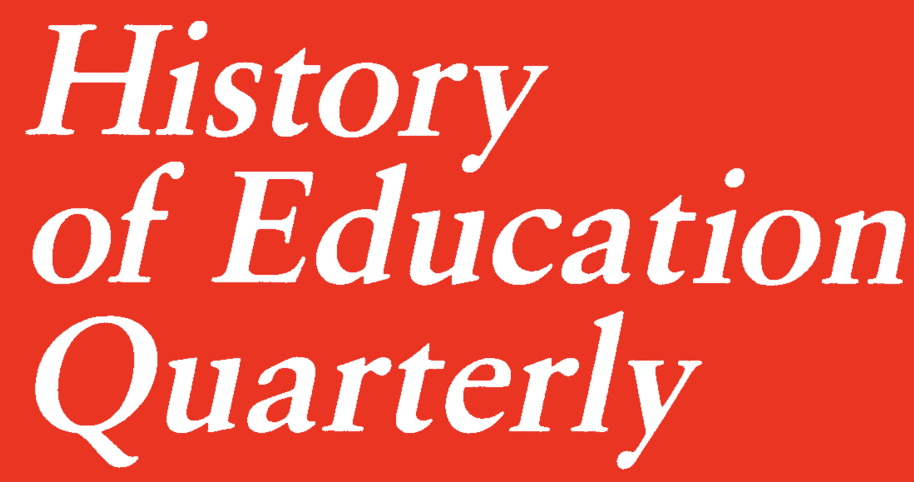

\title{
Summer 1990
}

Volum e 30

$\mathrm{Number}$ 


\title{
History of Education Society
}

The History of Education Society is an international scholarly society. Its purposes are to encourage and facilitate research in the history of education; to promote and improve the teaching of history of education; to encourage cooperation among specialists in history of education; and to promote an appreciation of the value of historical perspective in the making of educational policy. The Society is affiliated with the International Standing Conference for the History of Education, and members of the Society are automatically members of the Standing Conference.

\section{Officers (1990)}

\author{
President \\ Maxine Schwartz Seller, State University of \\ New York at Buffalo \\ Vice-President \\ DONALD WARREN, Indiana University \\ Secretary-Treasurer \\ David M. MENT, Teachers College, Columbia \\ University, 1987-1990 \\ Directors
N. Ray Hiner, Past President, 1989, University of
Kansas
Charles STRICKLAND, Emory University, 1987- 1990
LYNN D. GORDON, University of Rochester, 1988- 1991
BARBARA BREnZel, Wellesley College, 1989-1992

THE HISTORY OF EDUCATION SOCIETY AWARD: This award of $\$ 250$ will be made biennially to the best essay in the history of education published in any journal over the previous two years. The next award will be presented at the fall 1990 meeting of the History of Education Society. Any article published in 1988 or 1989 will be eligible for the award.

THE HENRY BARNARD PRIZE: This prize of $\$ 250$ is awarded biennially to the best essay in the history of education by a graduate student. The next award will be presented at the fall 1991 meeting of the History of Education Society. The recipient will have the essay published in the History of Education Quarterly.

The Society reserves the right not to make awards in years when the Prize Committee judges all entries to be of insufficient quality.

Inquiries regarding these awards should be directed to the chairperson of the Prize Committee: Robert Hampel, College of Education, Willard Hall, Room 219, University of Delaware, Newark, DE 19716.

OUTSTANDING BOOK AWARD: This award of $\$ 250$ is made biennially to the author of the best book published in the two previous years. The committee will accept nominations but will also make every effort to review all relevant works, whether or not they have been nominated. The award for books bearing 1989 and 1990 publication dates will be announced at the annual meeting of the Society in 1991.

Inquiries regarding the Outstanding Book Award should be directed to the chairperson of the committee: Maris Vinovskis, Dept. of History, University of Michigan, Ann Arbor, MI 48109. 


\section{History of Education Quarterly}

\section{Editorial Staff}

Editor

Associate Editor

Associate Editor

Managing Editor

Subscriptions Manager

Editorial Secretary
WILliam J. ReESE, Indiana University

RONALD D. COHEN, Indiana University-

Northwest

David W. Adams, Cleveland State University

AMY C. SCHUTT

Ted Stahly

Margaret A. Miller

\section{Editorial Board}

James C. AlbisetTI, University of Kentucky

RICHARD EDWARD ALDRICH, University of London Institute of Education

RONALD E. BUTCHART, SUNY College at Cortland

GERALDINE JONÇICH ClIFFORD, University of California, Berkeley

IAN E. DAVEY, University of Adelaide

Barry M. Franklin, Kennesaw State College

ROBERT D. GIDNEY, University of Western Ontario

DAVID F. LABAREE, Michigan State University

Ellen Condlffe Lagemann, Teachers College, Columbia University

JEFFREY MIREL, Northern Illinois University

Natalie NaYlor, Hofstra University

SHELDON ROTHBLATT, University of California, Berkeley

JOHN THELIN, College of William and Mary

DONALD WARREN, University of Maryland

SuE ZsCHOCHE, Kansas State University

The History of Education Quarterly (ISSN US 00182680 ) is published spring, summer, fall, and winter by the History of Education Society in cooperation with the School of Education, Indiana University, Bloomington, IN 47405, with additional support from Indiana University-Northwest and Cleveland State University. Membership in the Society, which includes subscription to the Quarterly, is available at the following rates: students, $\$ 15$; others, $\$ 25$ (non-U.S. members add $\$ 2$ to cover additional postage, surface mail; add $\$ 16$ for overseas airmail). Institutional subscription rates are: $\$ 47$, U.S.; $\$ 50$, non-U.S. All payment must be made in U.S. dollars. Single copies of some back issues available at $\$ 8$. Second-class postage paid at Bloomington, Ind. POSTMASTER: Send address changes to History of Education Quarterly, School of Education, Indiana University, Bloomington, IN 47405 .

History of Education Quarterly Vol. 30 No. 2 Summer 1990

Copyright 1990 by the History of Education Society. 


\section{History of Education Society}

INDIVIDUAL MEMBERSHIP: Membership is open to all persons interested in the study of the history of education. Membership provides for subscription to the History of Education Quarterly; subscription to Network, a newsletter published jointly with Division $\mathrm{F}$ of the American Educational Research Association; and receipt of the program of the annual meeting of the Society. Members of the Society are automatically members of the International Standing Conference for the History of Education. Membership offers subscription to publications on a calendar-year basis only. Dues are $\$ 15$ for students, $\$ 25$ for others. Non-U.S. members should add $\$ 2$ to cover additional postage for surface mail; $\$ 16$ for airmail. The portions of dues designated for support of the Quarterly are $\$ 15$ of student dues, $\$ 20$ of other individual dues. To become a member, send a check for the appropriate amount in U.S. dollars only to the History of Education Quarterly, School of Education, Indiana University, Bloomington, IN 47405. Make checks payable to History of Education Society. Indicate preferred mailing address and the calendar year in which your subscription should begin.

\section{History of Education Quarterly}

INSTITUTIONAL SUBSCRIPTIONS: Institutions may subscribe to the History of Education Quarterly directly (send checks to History of Education Quarterly, School of Education, Indiana University, Bloomington, IN 47405) or through subscription agencies. Rates are \$47, U.S.; \$50, non-U.S., U.S. dollars only.

BACK ISSUES: Some back issues are available (cost $\$ 8$ per issue).

INDEXES: Two indexes are available: Index to Vols. I-X (1961-1970), by Murray S. Shereshewsky (\$5) and Index to Vols. XI-XX (1971-1980), by Paul Mattingly and Marilyn Tobias (\$7). A set of both indexes may be purchased for $\$ 10$.

ARTICLE SUBMISSIONS: Contributions should be addressed to: Editor, History of Education Quarterly, School of Education, Indiana University, Bloomington, IN 47405. See last page of this issue for guidelines on submission. The editor will only consider articles that have been submitted exclusively to the History of Education Quarterly.

BOOK REVIEWS: Assignments of reviews are made from a file of potential reviewers by the associate editor. To have your name added to the file, send vita to the editor. Requests to review particular books cannot be honored.

The History of Education Quarterly is printed by Indiana University Printing Services. Design by Dennis H. Hill, Indiana University Publications. 


\section{History \\ of Education \\ Quarterly}

Volume $30 \cdot$ Number $2 \cdot$ Summer 1990

\section{Contents}

\section{Articles}

137 History of Education for the 1990s and Beyond: The

Case for Academic Imperialism

by N. Ray Hiner

161 A Gamble on Youth: Robert M. Hutchins, the University of Chicago and the Politics of Presidential Selection by Benjamin McArthur

187 Civic Education in Authoritarian Austria, 1934-38 by Carla Esden-Tempska

Essay Review

213 Students and Civil Rights in the 1960s by Jack Weinberg

\section{Book Reviews}

225 Boswell, The Kindness of Strangers

by David L. Ransel

227 Wiedemann, Adults and Children in the Roman Empire by Arther Ferrill

229 Ransel, Mothers of Misery

by John Bushnell

231 Shturman, The Soviet Secondary School

by Ben Eklof 
Phillips, Putting Asunder

by John R. Gillis

235

Oelkers, Reformpädagogik

by James C. Albisetti

237

Rempel, Hitler's Children

by Michael R. Marrus

Earle, The Making of the English Middle Class by Richard L. Greaves

Fuller, The Voice of Liberal Learning

by Erwin V. Johanningmeier

Huguet, Les inspecteurs généraux de l'instruction publique, and Chervel and Manesse, La dictée by Linda L. Clark

Stevenson and Wilson, Quality in Canadian Public Education

by Michael G. Fullan

Axelrod and Reid, Youth, University, and Canadian Society

by Theresa Richardson

Rubinger, An American Scientist in Early Meiji Japan by Michael Lewis

Barcan, Two Centuries of Education in New South Wales

by Malcolm Vick

Wolf, The Book Culture of a Colonial American City by William $D$. Liddle

Finkelstein, Governing the Young

by Polly Welts Kaufman

Cogan, All-American Girl

by Anne M. Boylan

259

Potts, Baptist Colleges

by David S. Webster

Kleinberg, The Shadow of the Mills

by Lisa M. Fine

Trennert, The Phoenix Indian School

by Steven J. Crum

Smock, Booker T. Washington in Perspective by Jacqueline A. Rouse 
Cuban, The Managerial Imperative

by Jerome T. Murphy

269 Butts, The Civic Mission in Educational Reform by Michael W. Sedlak

271 Grant, The World We Created at Hamilton High by William Graebner

$274 \quad$ Berrol, Getting Down to Business by Robert L. Church

277 Harvey et al., A Model of Its Kind by William G. Rothstein

279 Smith, Sports and Freedom by William J. Baker

281 Bender, The University and the City by Burton J. Bledstein 